\title{
Effect of different plants' aromatic essential oils on frozen Awassi lamb meat's chemical and
}

\section{physical characteristics}

\author{
Ahmed S.A. Al-Obaidi ${ }^{1}$, Ayad B. Mahmood ${ }^{2}$, Zaid K. Khidhir ${ }^{2, *}$, Hemn G. Zahir ${ }^{2}$, Ziyad T. Al-doori ${ }^{3}$, \\ Hiewa Othman Dyary ${ }^{4, *}$
}

\begin{abstract}
${ }^{1}$ Department of Animal Production, College of Agriculture, University of Diyala, Iraq; ${ }^{2}$ Department of Animal Sciences, College of Agricultural Engineering Sciences, University of Sulaimani, Iraq; ${ }^{3}$ Department of Public Health, College of Veterinary Medicine, University of Tikrit, Iraq; ${ }^{4}$ Department of Basic Sciences, College of Veterinary Medicine, University of Sulaimani, Sulaymaniyah, Iraq
\end{abstract}

*Corresponding Authors: Zaid K. Khidhir, Department of Animal Sciences, College of Agricultural Engineering Sciences, University of Sulaimani, Iraq. Email: Zaid.khzir@univsul.edu.iq; Hiewa Othman Dyary, Department of Basic Sciences, College of Veterinary Medicine, University of Sulaimani, Sulaymaniyah, Iraq. Email: dyary.othman@univsul.edu.iq

Received: 10 July 2021; Accepted: 2 November 2021; Published: 8 December 2021

(C) 2021 Codon Publications

OPEN ACCESS (c) $\underset{\mathrm{BY}}{\mathbf{\mathrm { NC }} \mathrm{SA}}$

PAPER

\begin{abstract}
The effect of drenching Awassi lambs with three aromatic essential oils from sage (Salvia officinalis L.), clove (Syzygium aromaticum L.), and laurel (Laurus nobilis L.) was investigated on meat chemical and physical characteristics, and oxidative and deterioration measurements. Twenty-four Awassi lambs, five to six months old, were divided into four groups. A concentrated diet was provided to the lambs at a rate of $3 \%$ of the body weight. The treatments were as follows: T1 was served as the untreated control, while T2, T3, and T4 were drenched with oils of sage, clove, and laurel, respectively. Drenching was carried out using water-soluble capsules containing $500 \mathrm{mg}$ oil/capsule/day. Treatments lasted 90 days. At the end of the treatment period, the animals were fasted overnight and slaughtered. The carcasses were cleaned and kept at $4{ }^{\circ} \mathrm{C}$ for $24 \mathrm{~h}$. The longissimus dorsi (LD) muscle was then separated and preserved in a plastic bag for three preservation periods: no freezing and 30 days and 60 days freezing at $-18^{\circ} \mathrm{C}$. Several physical, fat, and protein stability analyses of meat were done after the preservation periods. The results indicated no significant effect of drenching Awassi lambs with different aromatic essential oils on the meat's physical and chemical characteristics. However, these oils, especially clove oil, affected fat and protein stability with increasing preservation period by freezing.
\end{abstract}

Keywords: Awassi; essential oil; Laurus nobilis L.; meat; Salvia officinalis L.; Syzygium aromaticum L.

\section{Introduction}

Meat is classified as a perishable commodity due to its high moisture content and nutrient availability, making it suitable for microbial growth (Kumar et al., 2015, 2017). Meat contamination might occur at different stages, starting from the field and ending with the preparation for consumption, including slaughter, transportation, handling, storage, processing, marketing, and consumer's handling (Niyonzima et al., 2015). Treatments used to keep meat from contamination and spoilage vary with each stage, including heating, refrigeration, hydrostatic pressure, packaging, ionizing radiation, chemical preservatives, salts, and bioactive compounds. Selecting appropriate treatments to maintain the meat and meat products' hygiene depends on several factors (Chen et al., 2012).

Fats' oxidation and destruction by free radicals in cell membranes are natural processes affecting membrane 
transport and functions. Cell membrane phospholipids are rapidly affected by the oxidation process closely related to the fatty acids' saturation level. Free radicals react with these fatty acids and produce hydroperoxides that decompose to volatile aromatic compounds such as alkanes and aldehydes. These toxic substances affect animal products' nutritional value (Aminzare et al., 2019), safety for consumption, quality of meat, organoleptic characteristics, and storage period (Fernandes et al., 2018). Controlling free radicals' biological damage has recently become a topic of interest to researchers. Synthetic antioxidants such as butylated hydroxyanisole (BHA) and butylated hydroxytoluene (BHT) have been used commercially to prevent or reduce lipid peroxidation's unwanted effects. However, the demand to find or use plant-based natural compounds has recently increased, with consumers trying to protect meat and meat products from oxidation, spoilage, and pathogens (Aminzare et al., 2019; Veneziani et al., 2017). Natural antioxidants play an essential role in this field, protecting food from spoilage and maintaining public health. Essential oils are natural sources rich in antioxidants that inhibit free radicals such as phenolic compounds. These oils preserve animal fatty tissue and protect animal products from off-flavor and reactive oxygen resulting from oxidation of polyunsaturated fatty acids (Nitiema et al., 2012). Bioactive compounds such as essential oils improve food quality and protect consumers from the adverse effects of oxidative stress and microbial spoilage (Simitzis and Deligeorgis, 2011). Essential oils are complex mixtures of many ingredients and are mainly composed of terpenoids with low molecular weight aliphatic hydrocarbons such as aromatic aldehydes and phenols (Dorman and Deans, 2000). They have antimicrobial activities, as many studies have confirmed the antimicrobial effects of these oils when used with different foods, which extends the shelf life by reducing spoilage (Calo et al., 2015). For example, adding $0.25 \%$ cassia oil to refrigerated fresh chicken sausages increases the shelf life by $5-6$ days and lowers the microbial count (Sharma et al., 2017). In another study, it was found that wrapping chicken meat burgers with edible film incorporated with $0.10 \%$ oregano and $0.15 \%$ thyme essential oils increased shelf life up to 30 days (Soni et al., 2018).

Feed processing with antioxidants such as essential oils is one of the easiest ways to deliver these antioxidants to membrane phospholipids, reducing the oxidation from free radicals and protecting animal products such as meat from fat oxidation (Fasolato et al., 2015). Therefore, this method is considered the easiest and the most effective compared to the treatment of postmortem meat. There is a lack of sufficient research on using essential oils with Awassi sheep, the most common breed raised in Iraq. Fresh meat or meat refrigerated for 2-3 days is used for cooking. Finding a method to naturally increase the shelf-life without affecting the meat's quality and taste is important. Therefore, this research aimed to investigate the effects of three aromatic essential oils from sage (Salvia officinalis L.), clove (Syzygium aromaticum L.), and laurel (Laurus nobilis L.) on meat chemical and physical characteristics, and oxidative and deterioration measurements after different freezing periods.

\section{Materials and Methods}

\section{Extraction of volatile oil}

Dried seeds of clove (Syzygium aromaticum L.) and green leaves of sage (Salvia officinalis L.) and laurel (Laurus nobilis L.) were collected from local markets in Sulaymaniyah. The plants' identities were confirmed at the Department of Horticulture, Faculty of Agricultural Sciences, University of Sulaimani, where voucher specimens were deposited. The plants were dried in a freeze dryer and ground in a laboratory grinder. A hot oil extraction technique was used to extract oils. Then, water was added at a ratio of 5:1, and the mixture was subjected to hydro-distillation for $3 \mathrm{~h}$ using a Clevenger-type apparatus (Clevenger, 1928). The volatile oil content was calculated as a relative percentage $(\mathrm{v} / \mathrm{w})$. Later, the essential oil was extracted from the milled sample by the hydro-distillation method using the Clevenger set in $1000 \mathrm{~mL}$ distilled water and refrigerated until use (Ranjitha and Vijiyalakshmi, 2014).

\section{Animals and treatments}

Twenty-four Awassi lambs, 5-6 months old, with an average weight of $28.4 \mathrm{~kg}$, were divided according to weight into four treatment groups. The lambs were raised in individual cages and acclimatized for 2 weeks, followed by a treatment period lasting 90 days. During the experimental period, the lambs were fed a concentrated diet consisting of $35 \%$ wheat flour, $40 \%$ barley, $12 \%$ wheat bran, $10 \%$ soybean meal, $2.9 \%$ salt and limestone, and $0.1 \%$ premix. The energy content was $2791 \mathrm{cal} / \mathrm{kg}$, and the protein content was $13.75 / \mathrm{kg}$. Feed was provided to the lambs at $3 \%$ of their body weight. The lambs were subjected to weekly weight measurements, and the amount of feed was adjusted according to weight change.

The first group of lambs (T1) served as a control without drenching. Groups T2, T3, and T4 were drenched with sage oil, clove oil, and laurel oil, respectively. The drenching process was carried out using plastic syringes attached to a rubber tube. Each animal was given $0.5 \mathrm{~mL}$ of the extracted oil daily.

After the treatment period, the animals were fasted overnight and slaughtered. The carcasses were cleaned and 
kept for $24 \mathrm{~h}$ at $4^{\circ} \mathrm{C}$. Afterward, the longissimus dorsi (LD) muscle was separated, divided into several parts as appropriate, and each part was preserved in a plastic bag. Three preservation periods were used: zero freezing (P1), and 30-day freezing (P2) and 60-day freezing (P3) at $-18^{\circ} \mathrm{C}$.

\section{Physical measurements}

Several physical measurements were recorded on meat samples for each storage period, including $\mathrm{pH}$, water holding capacity (WHC) (Dolatowski and Stasiak, 1998), thaw loss, and cooking loss (Purchas and Barton, 2012).

\section{Chemical measurements}

Several chemical measurements were also made on the stored meat samples at the end of each storage period, including meat chemical composition (moisture, protein, ether extract, and ash) (Horwitz and Latimer, 2005), thiobarbituric acid (TBA) (Gheisari et al., 2010), total volatile nitrogen (TVN) (Pearson and Muslemuddin, 1971), and free fatty acids (FFA) (Pearson and Dustson, 1985).

\section{Statistical analysis}

SAS statistical analysis program was used to determine the effect of oil drenching and storage period on the studied measurements. Duncan's test was used to analyze the data to determine the effect of oil drenching and storage period on the studied measurements. Probability values of $\leq 0.05$ were considered statistically significant.

\section{Results}

There was no significant effect of oil treatments on the LD muscle $\mathrm{pH}$ in all preservation periods. In contrast, a significant increase in $\mathrm{pH}$ values $(\mathrm{P} \leq 0.05)$ occurred for most treatments with increasing freezing periods (Table 1). Also, different oils did not affect the LD muscle WHC according to the control for all preservation periods, while a significant decrease in WHC was observed for most treatments with increasing freezing periods.

Values are presented as mean \pm SEM. Different lowercase letters indicate significant differences between means within columns, while different uppercase letters indicate significant differences between means within rows $(\mathrm{P} \leq$ 0.05). WHC, water holding capacity.

No significant effects on thaw loss were observed for different oils and preservation periods, while a significant linear increase $(P \leq 0.05)$ in thaw loss was observed for all oils with increasing preservation periods of up to 60 days (Table 1). No significant cooking loss was observed in the treated groups for all preservation periods, while a significant decrease was diagnosed with increasing preservation periods.

Table 2 illustrates the effect of different oils and freeze-preservation periods on TBA, FFA, and TVN values of the LD muscle. The results indicated a decreasing effect of oil treatments on TBA, FFA, and TVN values in all treatment groups. Group T3 drenched with clove oil recorded the lowest values than the rest of the oil drenching treatments and the control for all preservation periods. Data also recorded a significant linear increase in TBA, FFA, and TVN values for all treatments, increasing the preservation period to 60 days.

Values are presented as mean \pm SEM. Different lowercase letters indicate significant differences between means within columns, while different uppercase letters indicate significant differences between means within rows $(\mathrm{P} \leq$ 0.05). TBA, thiobarbituric acid; TVN, total volatile nitrogen; FFA, free fatty acids.

Figure 1 shows the effect of different oil treatments and freeze-preservation periods on the LD muscles' chemical composition. There was no significant effect of oil treatments and preservation periods on the muscles' chemical components, despite decreasing moisture content and increased protein and fat content for all treatments with increasing preservation period.

\section{Discussion}

Maintaining meat's ultimate $\mathrm{pH}$ is very important because of its relationship to meat quality, color, and shelf life. Parvar et al. (2018) stated that feed additives, such as essential oils, had no significant effect on meat's final $\mathrm{pH} 24 \mathrm{~h}$ postmortem. Smeti et al. (2018) noted no significant effect of rosemary essential oils on lamb meat's final pH. Moreover, de Oliveira Monteschio et al. (2017) reported no significant effect of feeding clove and rosemary essential oils on final meat $\mathrm{pH}$. These results agree with the results achieved in this research (Table 1). The results also agreed with Rivaroli et al. (2020) and Ornaghi et al. (2020), who indicated that the average $\mathrm{pH}$ of LD is between 5.5 and 5.8. This value is influenced by chilling and the stress to which the animal is subjected before slaughter. The research data indicated that the meat $\mathrm{pH}$ of the animals was within the normal limits, indicating the animals were calm when slaughtered and the carcasses were cooled well. Microorganisms and meat enzymes cause proteolysis, producing organic sulfides, ammonia, and amines, which raise the $\mathrm{pH}$ (Muela 


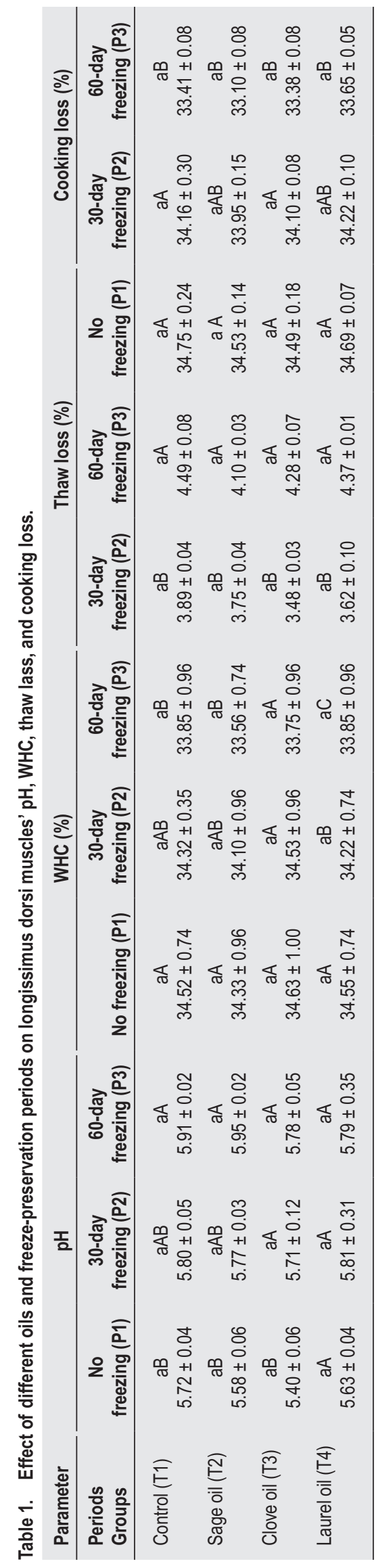


Table 2. Effect of different oils and freezing periods on longissimus dorsi muscles' TBA, FFA, and TVN.

\begin{tabular}{|c|c|c|c|c|c|c|c|c|c|}
\hline \multirow{2}{*}{$\begin{array}{l}\text { Parameter } \\
\text { Periods } \\
\text { Groups }\end{array}$} & \multicolumn{3}{|c|}{$\begin{array}{c}\text { TBA } \\
\text { mg malonaldehyde/kg }\end{array}$} & \multicolumn{3}{|c|}{$\begin{array}{l}\text { FFA } \\
(\%)\end{array}$} & \multicolumn{3}{|c|}{$\begin{array}{c}\text { TVN } \\
\mathrm{mg} \mathrm{N} / 100 \mathrm{~g} \\
\end{array}$} \\
\hline & $\begin{array}{c}\text { No } \\
\text { freezing } \\
\text { (P1) }\end{array}$ & $\begin{array}{l}\text { 30-day } \\
\text { freezing } \\
\text { (P2) }\end{array}$ & $\begin{array}{c}\text { 60-day } \\
\text { freezing } \\
\text { (P3) }\end{array}$ & $\begin{array}{c}\text { No } \\
\text { freezing } \\
(\mathrm{P} 1)\end{array}$ & $\begin{array}{c}\text { 30-day } \\
\text { freezing } \\
\text { (P2) }\end{array}$ & $\begin{array}{l}\text { 60-day } \\
\text { freezing } \\
\text { (P3) }\end{array}$ & $\begin{array}{c}\text { No } \\
\text { freezing } \\
(\mathrm{P} 1)\end{array}$ & $\begin{array}{c}\text { 30-day } \\
\text { freezing } \\
\text { (P2) }\end{array}$ & $\begin{array}{l}\text { 60-day } \\
\text { freezing } \\
\text { (P3) }\end{array}$ \\
\hline Control (T1) & $\begin{array}{c}a C \\
0.96 \pm 0.01\end{array}$ & $\begin{array}{c}a \mathrm{~B} \\
1.35 \pm 0.01\end{array}$ & $\begin{array}{c}\mathrm{aA} \\
1.58 \pm 0.02\end{array}$ & $\begin{array}{c}\mathrm{aC} \\
0.90 \pm 0.31\end{array}$ & $\begin{array}{c}a B \\
1.19 \pm 0.71\end{array}$ & $\begin{array}{c}\mathrm{aA} \\
1.42 \pm 0.28\end{array}$ & $\begin{array}{c}\mathrm{aC} \\
8.92 \pm 0.05\end{array}$ & $\begin{array}{c}a B \\
10.87 \pm 0.18\end{array}$ & $\begin{array}{c}\mathrm{aA} \\
12.15 \pm 0.39\end{array}$ \\
\hline Sage oil (T2) & $\begin{array}{c}b C \\
0.66 \pm 0.01\end{array}$ & $\begin{array}{c}b B \\
1.06 \pm 0.08\end{array}$ & $\begin{array}{c}b A \\
1.34 \pm 0.03\end{array}$ & $\begin{array}{c}b c C \\
0.66 \pm 0.25\end{array}$ & $\begin{array}{c}c B \\
0.84 \pm 0.36\end{array}$ & $\begin{array}{c}c A \\
0.98 \pm 0.21\end{array}$ & $\begin{array}{c}a b C \\
7.89 \pm 0.04\end{array}$ & $\begin{array}{c}b B \\
9.45 \pm 0.16\end{array}$ & $\begin{array}{c}b A \\
10.94 \pm 0.58\end{array}$ \\
\hline Clove oil (T3) & $\begin{array}{c}d B \\
0.47 \pm 0.02\end{array}$ & $\begin{array}{c}d A \\
0.77 \pm 0.02\end{array}$ & $\begin{array}{c}d A \\
0.76 \pm 0.08\end{array}$ & $\begin{array}{c}c C \\
0.51 \pm 0.17\end{array}$ & $\begin{array}{c}d B \\
0.68 \pm 0.85\end{array}$ & $\begin{array}{c}d A \\
0.82 \pm 0.34\end{array}$ & $\begin{array}{c}c B \\
5.24 \pm 0.59\end{array}$ & $\begin{array}{c}d A \\
6.75 \pm 0.19\end{array}$ & $\begin{array}{c}\mathrm{dA} \\
7.22 \pm 0.43\end{array}$ \\
\hline Laurel oil (T4) & $\begin{array}{c}c C \\
0.56 \pm 0.01\end{array}$ & $\begin{array}{c}c B \\
0.92 \pm 0.01\end{array}$ & $\begin{array}{c}c A \\
1.08 \pm 0.01\end{array}$ & $\begin{array}{c}a b C \\
0.82 \pm 0.20\end{array}$ & $\begin{array}{c}b B \\
0.96 \pm 0.43\end{array}$ & $\begin{array}{c}b A \\
1.21 \pm 0.22\end{array}$ & $\begin{array}{c}b C \\
7.04 \pm 0.19\end{array}$ & $\begin{array}{c}c B \\
8.17 \pm 0.23\end{array}$ & $\begin{array}{c}c A \\
9.32 \pm 0.30\end{array}$ \\
\hline
\end{tabular}

et al., 2010). This research agreed with the results that indicated increasing $\mathrm{pH}$ values corresponding to an increased storage period. Increase in $\mathrm{pH}$ value with increasing storage period of oil treatments was not at the same level in the control group. The increase in control treatment $\mathrm{pH}$ value may have resulted from proteolysis, reduced by the effect of oils and their active substances. The antimicrobial activity of essential oils is due to the presence of hydroxyl groups. This antimicrobial activity is mediated by several mechanisms, including influence on the cytoplasmic membrane and active transport (Sharma et al., 2020).

WHC is one of the most important measurements that determine meat quality and other characteristics. It is affected by many postmortem factors, including the extent of $\mathrm{pH}$ decline, proteolysis, and others (HuffLonergan and Lonergan, 2005). The results obtained in this research (Table 1) agree with Rivaroli et al. (2020), who indicated no significant effect of different essential oils on meat WHC. Ripoll et al. (2012) confirmed that WHC is greatly affected by meat $\mathrm{pH}$. The average $\mathrm{pH}$ values of the treated lambs' meat may explain the absence of differences in WHC values between these treatments. The results also agree with Muela et al. (2015), who observed a decrease in WHC with an increased freezing period. The degradation of meat protein and its decreased ability to hold water may explain this outcome. There is a positive relationship between WHC and $\mathrm{pH}$, as lactic acid production leads to a decrease in $\mathrm{pH}$. As the $\mathrm{pH}$ reaches the isoelectric point of meat proteins (especially myosin), the excess charges that bind the protein with water are minimal, resulting in decreased WHC. With an increase in the $\mathrm{pH}$ and its rise above the isoelectric point of proteins, the negative or positive charges that are not associated with the protein increase, enabling the proteins to bind more water molecules, resulting in increased WHC. In the case of freezing (as in this research), although the $\mathrm{pH}$ increased as a result of proteolysis, a decrease in WHC occurred.

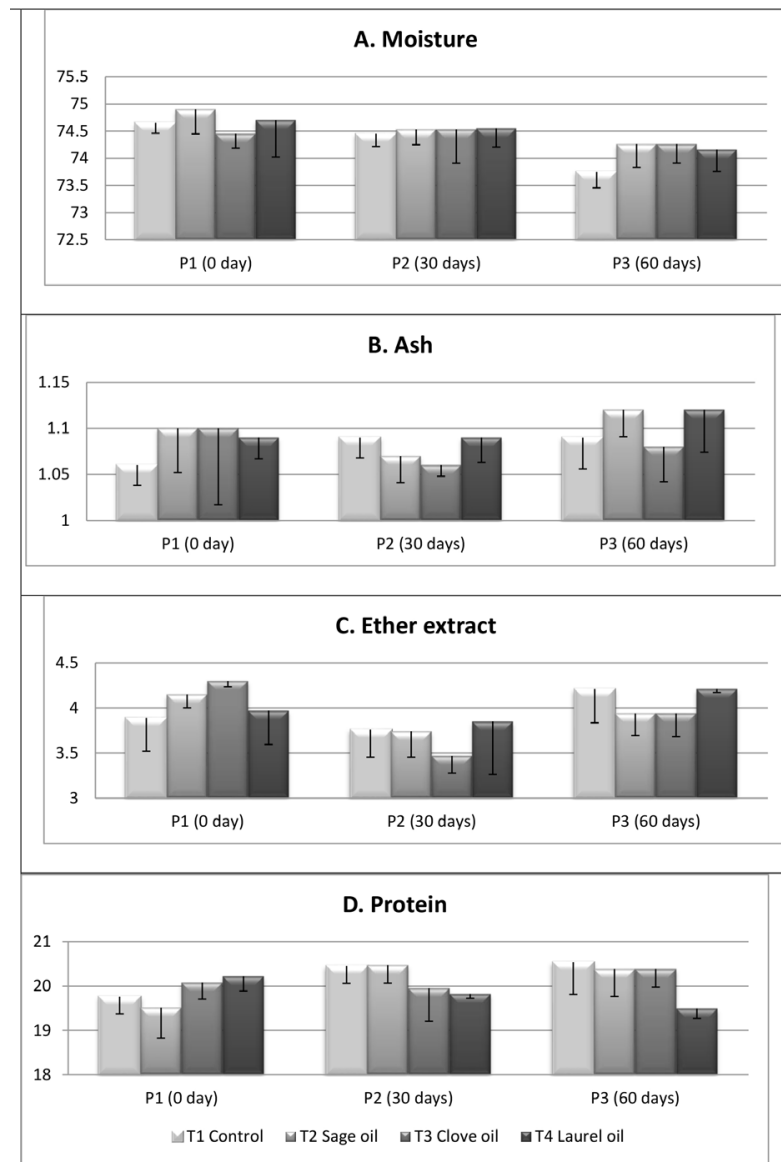

Figure 1. Effect of different oil treatments on the percentages of A. moisture, B. Ash, C. Ether extract, and D. Protein content of the treated lambs' longissimus dorsi muscles after different preservation periods.

This decrease may be due to the myofibril proteins shrinkage resulting from the presence of ice crystals that cause damage to muscle cells and denatured proteins, which increases in size with increasing storage period (Ripoll et al., 2012). 
This study indicated no significant effect of treatment with essential oils in cooking loss, which agrees with previous studies (de Oliveira Monteschio et al., 2017; Smeti et al., 2018). The results confirmed thawing losses with increasing preservation period and indicated a rise in total thaw loss with increased freezing time. These results coincide with previous studies (Muela et al., 2015; Ornaghi et al., 2020). Freezing increases thaw loss due to muscle membranes' mechanical damage by ice crystals, which leads to increased loss. Membrane damage may lead to increased protein denaturation and decreased WHC. Also, prolonged freezing causes increased water loss in meat by ice crystals damaging the cell membranes (Lu et al., 2019).

Fat and protein oxidations affect meat quality and are related to meat deterioration. TBA level is an indicator of the extent of lipid oxidation through malondialdehyde concentration and color intensity measurement. A TBA content of $0.6-2.0 \mathrm{mg}$ malondialdehyde $/ \mathrm{kg}$ is considered to be within normal limits (Falowo et al., 2014). The results revealed that the different essential oils decreased TBA levels. These results agreed with Parvar et al. (2018) and Ranucci et al. (2019). The oxidative indicator's decrease is because the essential oils are absorbed into the circulatory system ingestion, then distributed to muscles and the rest of the tissues (Velasco and Williams, 2011). Phenolic compounds are considered antioxidants due to their ability to inhibit free radicals by incorporating them into the aromatic ring (Maqsood et al., 2014). Nieto et al. (2010) stated that feed additives allow antioxidants such as essential oils to get into tissues and cellular membranes, protecting them from oxidative stress by reactive oxygen. This process has proven to be more effective than treating meat with antioxidants postmortem (Kumar et al., 2018).

The even distribution of antioxidants within the tissues and cells ensures the effectiveness of these compounds against fat and protein oxidation. The results in Table 2 also agreed with that reported by Politeo et al. (2006), who ranked 12 essential oils in the descending order according to their capacity as antioxidants, including the oils used in this research. They showed that the antioxidant efficacy of clove oil was the highest. Other studies recorded an increase in TBA relative to the increased storage time (Ranucci et al., 2019; Rivaroli et al., 2020). O'sullivan et al. (2004) stated that increased storage time leads to increased lipid oxidation, breakdown of peroxides, and increased secondary compounds resulting from oxidation, represented by malondialdehyde.

FFA is formed from fat and oil hydrolysis and is considered a measure of degradation by microorganisms and lipolytic enzymes (Rahman et al., 2015). The FFA results in Table 2 agreed with Ozogul et al. (2017), who observed a significant decrease in FFA for the different nano oil treatments and all preservation periods, compared with the control treatment. The results also indicated that a decrease in FFA is due to additives' ability to inhibit lipolytic bacteria growth (Maqsood et al., 2015; Rahman et al., 2020). Several hypotheses explain the essential oils and phenolic compounds' antimicrobial activity, but they are not yet proven (Kalogianni et al., 2020). Olatunde and Benjakul (2018) reported that essential oils could destroy bacteria by interacting with bacterial cell wall proteins. This interaction increases membranes' permeability and leaking of cytoplasmic structures and potassium ions, causing cell death (Bajpai et al., 2008). At the same time, other researchers reported that the decrease in $\mathrm{pH}$ and increase of phenols increased essential oils' hydrophobicity, favoring their attachment to pathogen's lipid cell membranes and increasing antimicrobial activity (Gutierrez et al., 2009). Due to their hydrophobic properties, phenolic compounds are bound with microbial membrane lipids causing their disruption (Devi et al., 2010; Trombetta et al., 2005). This disruption leads to intracellular compounds efflux, protein functional dysregulation, and cell death (Devi et al., 2010).

TVN is a product of meat and nonprotein nitrogenous substance degradation and a measure of meat deterioration. Degradation of nitrogenous substances is caused by microbial and endogenous proteolytic enzyme activity. This study's results agreed with Saleh et al. (2021), who reported decreased TVN values by feed additives, and Ozogul et al. (2017), who indicated a decrease in TVN following different nano oil treatments and storage times. The maximum permissible meat TVN content is 150 $\mathrm{mg} / \mathrm{kg}$. Research reports the antimicrobial effectiveness of phenolic compounds, which possibly destabilizes the bacterial cell membrane (Pisoschi et al., 2018), leading to permanent damage of the cell membrane and intracellular organelles and bacterial internal enzyme inhibition causing cell death. Besides, phenolic compounds' antioxidant efficacy may increase proteins' stability and reduce TVN by reducing radicals (Moroney et al., 2013). Our results confirmed increases in TVN values with increasing storage period. Custódio et al. (2018) indicated that TVN increases due to protein degradation by the internal meat enzymes and microorganisms' action.

This study's results revealed no significant effect of essential oils as feed additives on LD chemical composition. Other studies also reported similar results (Ranucci et al., 2019; Rivaroli et al., 2020). A decrease in moisture content with increasing storage time might occur due to protein denaturation, lack of WHC, and decomposition by microorganisms. This decrease in moisture leads to increased dry matter (protein ratios, ether extract, and ash) content (Al-Rubeii et al., 2009; Sharma et al., 2015). 


\section{Conclusion}

The results of this research indicated no significant effect of drenching Awassi lambs with different aromatic essential oils of sage, clove, and laurel at a concentration of 500 $\mathrm{mg} / \mathrm{head} /$ day on the physical and chemical characteristics of meat. However, these oils' effect was positive on fat oxidation and protein stability, increasing the preservation period, especially when using clove oil.

\section{References}

Al-Rubeii, A.M., Al-Kaisey, M. and Khadom, M., 2009. Effect of some natural and synthetic antioxidants on ground beef meat during cold storage. Alex J Fd Sci and Technol. 6: 1-16. https:// doi.org/10.21608/ajfs.2009.28816

Aminzare, M., Hashemi, M., Ansarian, E., Bimkar, M., Azar, H.H., Mehrasbi, M.R., Daneshamooz, S., Raeisi, M., Jannat, B. and Afshari, A., 2019. Using natural antioxidants in meat and meat products as preservatives: a review. Adv Anim Vet Sci. 7. https:// doi.org/10.17582/journal.aavs/2019/7.5.417.426

Bajpai, V.K., Shukla, S. and Kang, S.C., 2008. Chemical composition and antifungal activity of essential oil and various extract of Silene armeria L. Bioresour Technol. 99: 8903-8908. https://doi. org/10.1016/j.biortech.2008.04.060

Calo, J.R., Crandall, P.G., O’Bryan, C.A. and Ricke, S.C., 2015. Essential oils as antimicrobials in food systems - a review. Food Control. 54: 111-119. https://doi.org/10.1016/j.foodcont.2014. 12.040

Chen, J.H., Ren, Y., Seow, J., Liu, T., Bang, W.S. and Yuk, H.G., 2012. Intervention technologies for ensuring microbiological safety of meat: current and future trends. Compr Rev Food Sci Food Saf. 11: 119-132. https://doi.org/10.1111/j.1541-4337.2011.00177.x

Custódio, F.B., Vasconcelos-Neto, M.C., Theodoro, K.H., Chisté, R.C. and Gloria, M.B.A., 2018. Assessment of the quality of refrigerated and frozen pork by multivariate exploratory techniques. Meat Sci. 139: 7-14. https://doi.org/10.1016/j. meatsci.2018.01.004

de Oliveira Monteschio, J., de Souza, K.A., Vital, A.C.P., Guerrero, A., Valero, M.V., Kempinski, E.M.B.C., Barcelos, V.C., Nascimento, K.F. and do Prado, I.N., 2017. Clove and rosemary essential oils and encapsuled active principles (eugenol, thymol and vanillin blend) on meat quality of feedlot-finished heifers. Meat Sci. 130: 50-57. https://doi.org/110.1016/j.meatsci.2017.04.002

Devi, K.P., Nisha, S.A., Sakthivel, R. and Pandian, S.K., 2010. Eugenol (an essential oil of clove) acts as an antibacterial agent against Salmonella typhi by disrupting the cellular membrane. J Ethnopharmacol. 130: 107-115. https://doi.org/10.1016/j. jep.2010.04.025

Dolatowski, J. and Stasiak, D., 1998. The effect of low frequency and intensity ultrasound on pre-rigor meat on structure and functional parameters of freezing and thawed beef Semimembranosus muscle. In Proc 44th Int Cong Meat Sci Technol Barcelona, Spain.
Dorman, H.J. and Deans, S.G., 2000. Antimicrobial agents from plants: antibacterial activity of plant volatile oils. J Appl Microbiol. 88: 308-316. https://doi.org/10.1046/j.1365-2672. 2000.00969.x

Falowo, A.B., Fayemi, P.O. and Muchenje, V., 2014. Natural antioxidants against lipid-protein oxidative deterioration in meat and meat products: a review. Food Res Int. 64: 171-181. https://doi. org/10.1016/j.foodres.2014.06.022

Fasolato, L., Cardazzo, B., Balzan, S., Carraro, L., Taticchi, A., Montemurro, F. and Novelli, E., 2015. Minimum bactericidal concentration of phenols extracted from oil vegetation water on spoilers, starters and food-borne bacteria. Ital J Food Saf. 4: 4519. https://doi.org/4519.10.4081/ijfs.2015.4519

Fernandes, R.D.P.P., Trindade, M.A. and de Melo, M.P., 2018. Natural antioxidants and food applications: healthy perspectives. In: Alternative and replacement foods. Elsevier, pp. 31-64.

Gheisari, H.R., Møller, J.K.S., Adamsen, C.E. and Skibsted, L.H., 2010. Sodium chloride or heme protein induced lipid oxidation in raw, minced chicken meat and beef. Czech J Food Sci. 28: 364-375. https://doi.org/10.17221/182/2009-CJFS

Govaris, A., Botsoglou, E., Florou-Paneri, P., Moulas, A. and Papageorgiou, G., 2005. Dietary supplementation of oregano essential oil and-tocopheryl acetate on microbial growth and lipid oxidation of turkey breast fillets during storage. Int J Poult Sci. 4: 969-975. https://doi.org/10.3923/ijps.2005.969.975

Gutierrez, J., Barry-Ryan, C. and Bourke, P., 2009. Antimicrobial activity of plant essential oils using food model media: efficacy, synergistic potential and interactions with food components. Food Microbiol. 26: 142-150. https://doi.org/10.1016/j. fm.2008.10.008

Horwitz, W. and Latimer, G.W., 2005. Official methods of analysis of AOAC International. Gaithersburg, MD: AOAC International.

Huff-Lonergan, E. and Lonergan, S.M., 2005. Mechanisms of water-holding capacity of meat: the role of postmortem biochemical and structural changes. Meat Sci. 71: 194-204. https:// doi.org/10.1016/j.meatsci.2005.04.022

Kalogianni, A.I., Lazou, T., Bossis, I. and Gelasakis, A.I., 2020. Natural phenolic compounds for the control of oxidation, bacterial spoilage, and foodborne pathogens in meat. Foods. 9: 794. https://doi.org/10.3390/foods9060794.

Kumar, S., Mendiratta, S., Agrawal, R.K., Sharma, H. and Kumar, R., 2017. Quality evaluation of mutton nuggets incorporated with optimized level of flaxseed flour. Nutr. Food Sci. 47: 67-77. https://doi.org/10.1108/NFS-07-2015-0081

Kumar, S., Mendiratta, S., Agrawal, R.K., Sharma, H. and Singh, B., 2018. Antioxidant and antimicrobial properties of mutton nuggets incorporated with blends of essential oils. J Food Sci Technol. 55: 821-832. https://doi.org/10.1007/s13197-0173009-6

Kumar, A., Mendiratta, S., Sen, A., Kandeepan, G., Talukder, S., Sharma, H., Soni, A., Irshad, A. and Kumar, S., 2015. Preparation and storage stability of meat spread developed from spent hens. Vet World. 8: 651. https://doi.org/10.14202/ vetworld.2015.651-655

Lu, X., Zhang, Y., Zhu, L., Luo, X. and Hopkins, D.L., 2019. Effect of superchilled storage on shelf life and quality characteristics of 
M. longissimus lumborum from Chinese Yellow cattle. Meat Sci. 149: 79-84. https://doi.org/10.1016/j.meatsci.2018.11.014.

Maqsood, S., Abushelaibi, A., Manheem, K., Al Rashedi, A. and Kadim, I.T., 2015. Lipid oxidation, protein degradation, microbial and sensorial quality of camel meat as influenced by phenolic compounds. LWT-Food Sci Technol. 63: 953-959. https:// doi.org/10.1016/j.lwt.2015.03.106

Maqsood, S., Benjakul, S., Abushelaibi, A. and Alam, A., 2014. Phenolic compounds and plant phenolic extracts as natural antioxidants in prevention of lipid oxidation in seafood: a detailed review. Compr Rev Food Sci Food Saf. 13: 1125-1140. https:// doi.org/10.1111/154.1-4337.12106

Moroney, N., O'grady, M., O'doherty, J. and Kerry, J., 2013. Effect of a brown seaweed (Laminaria digitata) extract containing laminarin and fucoidan on the quality and shelf-life of fresh and cooked minced pork patties. Meat Sci. 94: 304-311. https://doi. org/10.1016/j.meatsci.2013.02.010

Muela, E., Monge, P., Sañudo, C., Campo, M.M. and Beltrán, J.A., 2015. Meat quality of lamb frozen stored up to 21 months: instrumental analyses on thawed meat during display. Meat Sci. 102: 35-40. https://doi.org/10.1016/j.meatsci.2014.12.003

Muela, E., Sañudo, C., Campo, M.M., Medel, I. and Beltrán, J.A., 2010. Effect of freezing method and frozen storage duration on instrumental quality of lamb throughout display. Meat Sci. 84: 662-669. https://doi.org/10.1016/j.meatsci.2009.10.028

Nieto, G., Díaz, P., Bañón, S. and Garrido, M.D., 2010. Dietary administration of ewe diets with a distillate from rosemary leaves (Rosmarinus officinalis L.): influence on lamb meat quality. Meat Sci. 84: 23-29. https://doi.org/10.1016/j.meatsci.2009.08.001

Nitiema, L.W., Savadogo, A., Simpore, J., Dianou, D. and Traore, A.S., 2012. In vitro antimicrobial activity of some phenolic compounds (coumarin and quercetin) against gastroenteritis bacterial strains. Int J Microbiol Res. 3: 183-187. https://doi. org/10.5829/idosi.ijmr.2012.3.3.6414

Niyonzima, E., Ongol, M.P., Kimonyo, A. and Sindic, M., 2015. Risk factors and control measures for bacterial contamination in the bovine meat chain: a review on Salmonella and pathogenic $E$. coli. J Food Res. 4. https://doi.org/10.5539/jfr.v4n5p98

O’sullivan, C.M., Lynch, A.-M., Lynch, P.B., Buckley, D.J. and Kerry, J.P., 2004. Assessment of the antioxidant potential of food ingredients in fresh, previously frozen and cooked chicken patties. Int J Poult Sci. 3: 337-344.

Olatunde, O.O. and Benjakul, S., 2018. Natural preservatives for extending the shelf-life of seafood: a revisit. Compr Rev Food Sci Food Saf. 17: 1595-1612. https://doi.org/10.1111/1541-4337.12390

Ornaghi, M.G., Guerrero, A., Vital, A.C.P., de Souza, K.A., Passetti, R.A.C., Mottin, C., de Araújo Castilho, R., Sañudo, C. and do Prado, I.N., 2020. Improvements in the quality of meat from beef cattle fed natural additives. Meat Sci. 163: 108059. https://doi. org/10.1016/j.meatsci.2020.108059

Ozogul, Y., Yuvka, İ., Ucar, Y., Durmus, M., Kösker, A.R., Öz, M. and Ozogul, F., 2017. Evaluation of effects of nanoemulsion based on herb essential oils (rosemary, laurel, thyme and sage) on sensory, chemical and microbiological quality of rainbow trout (Oncorhynchus mykiss) fillets during ice storage. LWT-Food Sci Technol. 75: 677-684. https://doi.org/10.1016/j.lwt.2016.10.009
Parvar, R., Ghoorchi, T., Kashfi, H. and Parvar, K., 2018. Effect of Ferulago angulata (Chavil) essential oil supplementation on lamb growth performance and meat quality characteristics. Small Rumin Res. 167: 48-54. https://doi.org/10.1016/j. smallrumres.2018.07.026

Pearson, A. and Dustson, T., 1985. Advance in meat research. Avi. Publishing Company. Inc., Westport, CT.

Pearson, D. and Muslemuddin, M., 1971. Accurate determination of total volatile nitrogen in meat and fish. Assoc Public Anal J. $28-29$.

Pisoschi, A.M., Pop, A., Georgescu, C., Turcuş, V., Olah, N.K. and Mathe, E., 2018. An overview of natural antimicrobials role in food. European Journal of Medicinal Chemistry 143: 922-935. https://doi.org/10.1016/j.ejmech.2017.11.095

Politeo, O., Jukić, M. and Miloš, M., 2006. Chemical composition and antioxidant activity of essential oils of twelve spice plants. Croat Chem Acta. 79: 545-552.

Purchas, R.W. and Barton, R.A., 2012. The tenderness of meat of several breeds of cattle raised under New Zealand pastoral conditions. New Zealand J Agric Res. 19: 421-428. https://doi.org/1 0.1080/00288233.1976.10420970

Rahman, M., Alam, M., Monir, M. and Rahman, S., 2020. Effect of Moringa oleifera leaf extract and synthetic antioxidant on quality and shelf-life of goat meat nuggets at frozen storage. Int J Food Res. 7: 34-45.

Rahman, M., Hossain, M., Rahman, S., Amin, M. and Oh, D.-H., 2015. Evaluation of physicochemical deterioration and lipid oxidation of beef muscle affected by freeze-thaw cycles. Korean J Food Sci Anim Resour. 35: 772-782. https://doi.org/10.5851/ kosfa.2015.35.6.772

Ranjitha, J. and Vijiyalakshmi, S., 2014. Facile methods for the extraction of essential oil from the plant species - a review. IJPSR. 5: 1107-1115.

Ranucci, D., Branciari, R., Cobellis, G., Acuti, G., Miraglia, D., Olivieri, O., Roila, R. and Trabalza-Marinucci, M., 2019. Dietary essential oil mix improves oxidative stability and hygienic characteristic of lamb meat. Small Rumin Res. 175: 104-109. https:// doi.org/10.1016/j.smallrumres.2019.04.012

Ripoll, G., Albertí, P. and Joy, M., 2012. Influence of alfalfa grazing-based feeding systems on carcass fat colour and meat quality of light lambs. Meat Sci. 90: 457-464. https://doi.org/10.1016/j. meatsci.2011.09.007

Rivaroli, D.C., del Mar Campo, M., Sañudo, C., Guerrero, A., Jorge, A.M., Vital, A.C.P., Valero, M.V., do Prado, R.M. and do Prado, I.N. 2020. Effect of an essential oils blend on meat characteristics of crossbred heifers finished on a high-grain diet in a feedlot. Anim Prod Sci. 60: 595-602. https://doi.org/10.1071/AN18620

Sharma, H., Mendiratta, S., Agrawal, R. and Kandeepan, G., 2015. Effect of clove and holybasil essential oil on sensory and microbiological quality of fresh chicken sausages. J Meat Sci Technol. 3: $37-41$.

Sharma, H., Mendiratta, S., Agarwal, R. and Gurunathan, K., 2020. Bio-preservative effect of blends of essential oils: natural antioxidant and anti-microbial agents for the shelf life enhancement of emulsion based chicken sausages. J Food Sci Technol. 57: 30403050. https://doi.org/10.1007/s13197-020-04337-1 
Sharma, H., Mendiratta, S., Agarwal, R., Kumar, S. and Soni, A., 2017. Evaluation of antioxidant and anti-microbial activity of various essential oils in fresh chicken sausages. J Food Sci Technol. 54: 279-292. https://doi.org/10.1007/s13197-016-2461-z

Simitzis, P. and Deligeorgis, S., 2011. The effects of natural antioxidants dietary supplementation on the properties of farm animal products. In: Animal feed: types, nutrition, safety. Nova Science Publishers, Inc., New York, NY, pp. 155-168.

Smeti, S., Hajji, H., Mekki, I., Mahouachi, M. and Atti, N., 2018. Effects of dose and administration form of rosemary essential oils on meat quality and fatty acid profile of lamb. Small Rumin Res. 158: 62-68. https://doi.org/10.1016/j.smallrumres.2017.10.007

Soni, A., Gurunathan, K., Mendiratta, S., Talukder, S., Jaiswal, R. and Sharma, H., 2018. Effect of essential oils incorporated edible film on quality and storage stability of chicken patties at refrigeration temperature $(4 \pm 1$ C). J Food Sci Technol. 55: 3538-3546. https://doi.org/10.1007/s13197-018-3279-7

Trombetta, D., Castelli, F., Sarpietro, M.G., Venuti, V., Cristani, M., Daniele, C., Saija, A., Mazzanti, G. and Bisignano, G., 2005. Mechanisms of antibacterial action of three monoterpenes. Antimicrob Agents Chemother. 49: 2474-2478. https://doi. org/10.1128/AAC.49.6.2474-2478.2005

Velasco, V. and Williams, P., 2011. Improving meat quality through natural antioxidants. Chil J Agric Res. 71: 313-322. https://doi. org/10.4067/S0718-58392011000200017

Veneziani, G., Novelli, E., Esposto, S., Taticchi, A. and Servili, M., 2017. Applications of recovered bioactive compounds in food products. In: Olive mill waste: recent advances for sustainable management. Elsevier, pp. 231-253. https://doi.org/10.1016/ B978-0-12-805314-0.00011-X 